\title{
Evaluating the Quality of E-learning Material
}

\author{
Ilze Kazaine \\ Latvia University of Agriculture
}

\begin{abstract}
An increasing number of educational institutions in the study process uses one of the e-learning systems. Consequently, more and more students are offered learning materials in electronic format. E-materials in distance learning and e-learning is one of the most important elements, therefore much attention and enough time should be paid for their development. There are a number of studies on e-learning quality, where criteria of quality are discussed in the context of chosen e-learning environment and the process of implementation. This article examines only the quality of ematerial. The aim was to find a way to reduce the effort and time of electronic learning material quality evaluation. The study used content analysis by summarizing the most important factors influencing the quality for teaching materials. Based on the quality criteria mentioned in the literature and personal experience, a criterion, which affects quality of elearning material, were summarized and grouped. The criteria were grouped into four groups resulting from didactic, media, usability and formal quality. Quality evaluation is performed by using one of the methods used in software engineering - checklist. Based on the identified quality criteria a checklist was established. In order to facilitate the evaluation process a web-based tool is offered. The tool includes a defined checklist with assessment rating scale and three levels of impact. Evaluation of material quality is shown in the terms of percentage. After testing the tool, it could be used for course developers, program managers or other persons involved in evaluation process of e-learning resources.
\end{abstract}

Keywords: checklist, evaluation, quality indicators, self-assessment tool.

\section{INTRODUCTION}

Any company's goal is to provide quality service or sell a quality product. According to the general definitions, quality is a set of features and characteristics of a product or service that relates to its ability to satisfy certain or planned needs [1]. In the distance learning quality is defined as the characteristic or set of properties that characterizes object, event or process compliance with certain previously appointed requirements [2]. However, requirements are determined by two main factors: customers and legislation. Often, when it comes to elearning quality, then the interpretation is quite differing. Its definition depends on the stakeholders' point of view. In the distance learning quality is defined as the characteristic or set of characteristics of the object, phenomenon and process compliance with certain prior requirements [3]. There are a number of project activities and organizations studies that relate to quality of e-learning and distance learning. Quality is mainly focused on the use of resources to achieve specific goals. There are a number of recommendations on e-environment choice, process organization, accessibility of education, adaptation of learning environment for personal characteristics and needs. In order to support a common understanding of quality and organizations, providing e-learning services, could be able to provide the appropriate quality, the studies have been conducted. Studies have analysed approaches and the aim of studies is to establish unified quality criteria for e-learning [4].

There are now a number of organizations and educational institutions, who have created their products for quality assessment [5]. Depending on the target object (lecture, course, institution), these criteria are focused either on design or usability, on didactics, or to learning process. As shown by study of E.Bratengeyer and G.Schwede, the most commonly occurring criteria is pedagogy, didactics and media design, the quality of the content [5]. Emphasizing the significance of learning material content quality, exactly these quality indicators were analysed in this study. For the company or institution providing distance learning services, it is essential not only to provide service and organization, but also quality of e-learning materials used in the process. Its basic requirements are resulting from learning content, which in turn is determined by the corresponding educational standard. Quality assessment has an internal dimension - selfassessment and external dimension carried out by external experts. Project implementer or creator of elearning material can implement self-assessment by using a checklist.

Checklists are being used in the case of evaluation several aspects of product quality or separate stages of process. Them used in quality assurance of software engineering, to check process compliance, code standardization and error prevention, and others. 
Checklist is a list of items required, things to be done, or points to be considered, used as a reminder [6]. With the help of a checklist it is possible to determine conformity of content to quality indicators. Checklist is a character or a list of activities in which the observer makes notes [7]. Checklists have been used in numerous evaluations and have been considered as a helpful tool for quality assessment. In many cases, only if there is compliance with certain criteria, there is a further evaluation using other methods. Checklists help evaluators monitor criteria during an evaluation process. Wingate [8] noted that the most basic type of checklist can be useful in conducting an evaluation in many aspects. Checklist can be short and simple list of some of the elements, but can also be a complex surveillance system with precise definitions of expected behaviour. In any case, the development of checklist should be taken into account for assessment of work analysis, analysis of objectives and tasks.

The aim of the research was to find way to minimize the effort and time required for evaluation of the electronic learning materials. This article describes the checklist as a quality assessment tool, its creation and application to e-learning.

\section{MATERIALS AND METHODS}

Monographic method has been used for this article. Information was searched in electronic databases and printed publications, published in Europe. Broad spectrum is discussed and analysed the scientific literature on quality evaluation of e-learning material, factors influencing quality and most important characteristics of the period from 2004 to 2016.

The study used content analysis by summarizing the most important factors influencing the quality of the e-learning materials. A checklist was created based on the collected quality criteria which are mentioned in the reviewed literature (15 sources) and based on the author's experience, obtained while working as a teacher from 1997 to 2014 at the Latvia University of Agriculture and from 2014 at the Professional Distance Learning Centre of Latvia. To evaluate teaching materials checklist questions (total 86 questions) were evaluated and adjusted in conversations and discussions in the work and educational environment. In September and October of 2016 unstructured interviews were conducted with both teachers and distance learning students in an informal atmosphere.

\section{RESULTS AND DISCUSSION}

In sources of information on e-learning the most emphasis is on following criteria: content, navigation, design of text and graphics, learning tasks and feedback [9], [10]. Of course the most important element is the Content [11]-[17]. Any electronic learning material fall into three types: technical parts, learning units and learning entities [14]. In this study attention has been brought to the quality criteria relating to content of learning units. Quality criteria are grouped into four sections according to their nature - criteria relating to didactics, technical requirements of media, usability. Individually isolated is formal criteria, which have the greatest impact on the overall quality of the material. Table 1 shows the list of the quality indicators used in the various E-Learning systems.

Table I

List of quality criteria

\begin{tabular}{|c|c|c|}
\hline $\begin{array}{l}\text { Quality } \\
\text { Criteria }\end{array}$ & Quality Subcriteria & Reference \\
\hline \multirow[t]{7}{*}{ Formal } & $\begin{array}{l}\text { Segmenting, text } \\
\text { structuring }\end{array}$ & $\begin{array}{l}{[16],[18],[19],[20],[21],} \\
{[23]}\end{array}$ \\
\hline & $\begin{array}{l}\text { Grammatical and } \\
\text { spelling errors }\end{array}$ & {$[16],[19]$} \\
\hline & language & [16], [18], [19] \\
\hline & topicality & {$[19]$} \\
\hline & Literature sources & [16], [19] \\
\hline & $\begin{array}{l}\text { Copyright } \\
\text { compliance }\end{array}$ & [19], [23] \\
\hline & Review of Version & [19] \\
\hline \multirow[t]{6}{*}{ Didactic } & Course Objectives & {$[4],[15],[16],[19]-[21]$} \\
\hline & Course Assessments & {$[4],[15],[16],[19],[20]$} \\
\hline & Target group & [19] $-[21],[23]$ \\
\hline & media choice & {$[4],[16],[20]$} \\
\hline & Course metadata & {$[4],[16],[18],[19]$} \\
\hline & $\begin{array}{l}\text { compliance with the } \\
\text { curriculum }\end{array}$ & [20], [22], [23] \\
\hline \multirow[t]{8}{*}{ Media } & Corporate Design & [19] \\
\hline & Content Layout & [4], [15], [16], [19], [22] \\
\hline & Graphics and Fonts & [16], [19], [21] \\
\hline & Multimedia & {$[4],[15],[16],[19],[22]$} \\
\hline & $\begin{array}{l}\text { Design of text and } \\
\text { graphics }\end{array}$ & [16], [18], [19], [21] \\
\hline & $\begin{array}{l}\text { External content } \\
\text { resources }\end{array}$ & {$[4],[15],[18],[21],[23]$} \\
\hline & Search & [19] \\
\hline & Material load time & {$[16],[18]$} \\
\hline \multirow[t]{6}{*}{ Usability } & Navigation & {$[16],[18],[19],[21],[23]$} \\
\hline & Functionality & {$[18]-[20]$} \\
\hline & Perception & [19], [20] \\
\hline & Accessibility & {$[16],[19],[21]$} \\
\hline & $\begin{array}{l}\text { Alternative } \\
\text { provision }\end{array}$ & [19], [20] \\
\hline & $\begin{array}{l}\text { Learning tasks and } \\
\text { feedback }\end{array}$ & {$[18],[21],[23]$} \\
\hline
\end{tabular}

From an analytical point of view, the existing works helps to obtain a complete overview of the various aspects, which have be considered in order to provide quality of the e-learning material. With critical assessment it can be concluded that the major attention is on the didactic aspect and the appropriate use of media. Less often mentioned is criteria, which relates to the material adaptation for people with special needs.

During the research a web-based self-assessment tool was developed for e-learning material content quality evaluation. This tool can be used by course developers, program managers or other persons involved in the evaluation process of e-learning 
resources. It is based on a checklist, which is grouped into four sections:

- Formal quality;

- Didactic;

- Media;

- Usability.

Checklist is prepared according to the identified quality sub-criteria. The evaluation uses a rating scale from 1 (doesn't comply) to 5 (fully meets) and three impact levels: low, medium, high (Fig. 1). After evaluation of the material also quantitative assessment is given. It is shown in both -by all the four sections and the overall average rating.

\begin{tabular}{|c|c|c|c|}
\hline \multicolumn{4}{|c|}{ Mãcỉbu materiāla raksturojums } \\
\hline $\begin{array}{l}\text { Materiāla nosaukums } \\
\text { Materiāla tips" }\end{array}$ & \multicolumn{3}{|l|}{\begin{tabular}{|l} 
\\
teksts $\quad V$
\end{tabular}} \\
\hline \multicolumn{4}{|l|}{ obligäts } \\
\hline \multicolumn{4}{|l|}{ Materiāla vērtējums } \\
\hline Klasteris & \multicolumn{3}{|l|}{ formâlä kvalițte $\vee$} \\
\hline \multicolumn{4}{|l|}{ Formālā kvalitāte } \\
\hline \multicolumn{4}{|c|}{ 1. Teksta izklāsts un gramatiska } \\
\hline \multicolumn{4}{|c|}{ 1.1. Teksts ir gramatiski pareizi formulêts, nav gramatisko kḷūdu. } \\
\hline Vêtrējums: & $\bigcirc 1 \bigcirc 2 \bigcirc 3 \bigcirc 4 \bigcirc 5$ & $\square$ nav aktuāls & Ietekme: zema $\checkmark$ \\
\hline \multicolumn{4}{|c|}{ 1.2. Teksta saturs ir atbilstošs têmai. } \\
\hline Vềtējums: & $\bigcirc 1 \bigcirc 2 \bigcirc 3 \bigcirc 4 \bigcirc 5$ & $\square$ nav altuāls & Ietekme: zema $\checkmark$ \\
\hline \multicolumn{4}{|c|}{ 1.3. Teksta izklāsts ir atbilstošs mērḳa grupai. } \\
\hline Vêrtējums: & $\bigcirc 1 \bigcirc 2 \bigcirc 3 \bigcirc 4 \bigcirc 5$ & $\square$ nav aktuāls & Ietekme: zems $\vee$ \\
\hline \multicolumn{4}{|c|}{ 1.4. Teksta izklāsts ir saprotams. } \\
\hline Vêrtējums: & $\bigcirc 1 \bigcirc 2 \bigcirc 3 \bigcirc 4 \bigcirc 5$ & $\square$ nav altuāls & Ietekme: zema V \\
\hline \multicolumn{4}{|c|}{ 1.5. Teksta izklāstā nav lietoti personvārdi. } \\
\hline Vêrtējums: & $\bigcirc 1 \bigcirc 2 \bigcirc 3 \bigcirc 4 \bigcirc 5$ & $\square$ nav aktuāls & Ietekme: zema $\vee$ \\
\hline
\end{tabular}

Fig. 1. The view of e-learning material content quality evaluation tool - formal quality evaluation part.

After evaluation of the material also quantitative assessment is given. It is shown in both - by all the four sections and the overall average rating (Fig. 2).

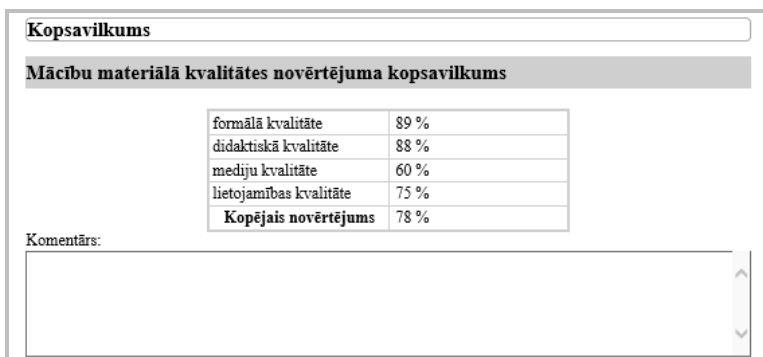

Fig. 2. The view of e-learning material content quality evaluation tool - summary of quality.

The developed web-based self-assessment tool is still in the testing stage and its activities remain to be tested in real work environment.

\section{CONCLUSIONS}

The main quality criteria have been identified and grouped according to their effect. Mainly they are based on the technical requirements, but also cover didactical aspects. Based on these criteria has been created a checklist. E-learning material assessment checklist has two main roles:
- a tool to guide a discussion between evaluators and material developers regarding the preferred contents of e-learning materials;

- a tool that can use the course developers to evaluate the material already in the development phase.

Checklist provides guidelines for course content for developer about whether it is necessary to improve the e-learning materials, allow identify weaknesses in the material that need improvement. Course developers themselves can use the checklist as a monitoring and reflection tool. Checklist allows identifying a number of conditions and requirements that needs be taken into account in the development of e-learning materials. To improve assessment process of materials, a web-based self-assessment tool was created. Electronic checklist tool is intended to help assessors to evaluate the final product - the electronic learning materials, that is, whether it meets the expected quality. The research should continue to evaluate the usefulness of the developed checklist tool.

\section{REFERENCES}

[1] Latvijas Nacionālā standartizācijas institūcija „Latvijas standarts", "Informācija un dokumentācija - Vārdnīca," (Information and documentation - Vocabulary), standarts LVS ISO 5127:2005, 2005. (In Latvian)

[2] J. Dzelme, A. Kapenieks, M. Upmale, L. Jermolajeva, V. Vikmane, A. Rengarte, I. Buligina, B. Žuga, Dz. Tomsons, S. Gibže un A. Škute, Tālākizglītības kvalitātes vērtēšanas rokasgrāmata. (Quality Assessment Guide of Distance learning) Rīga: Lielvārds, 2001, 32.lpp. (In Latvian)

[3] U.-D. Ehlers, "Quality in e-learning from a learner's perspective," European Journal for Distance and Open Learning, [Online]. Available: http://www.eurodl.org/ materials/contrib/2004/Online Master_COPs.html. [Accessed January 16, 2017].

[4] E. Bratengeyer, A. Bubenzer, J. Jäger und G. Schwed, eLearning Qualitäts-Evaluationstool. (E-learning quality evaluation tool ) Books on Demand, 2015. (In German)

[5] E. Bratengeyer and G. Schwed, "eLQe: A Cool Tool for Simply Evaluating Your E-learning Course Development," In: Proceedings of the Eighth International Conference on ELearning in the Workplace, 2016, New York, USA. [Online]. Available: https://www.icelw.org/proceedings/2016/ICELW 2016/Papers/Bratengeyer_Schwed.pdf [Accessed February 6, 2017].

[6] Oxford Dictionary of English, Oxford University Press: Oxford, 2010, 2112 p.

[7] A. Geske un A Grīnfelds, Testu teorijas elementi izglītībā. (Test theory in education) LU projekta „Profesionālajā izglītībā iesaistīto vispārizglītojošo mācību priekšmetu pedagogu kompetences paaugstināšana" materiāls, vienošanās Nr.2009/0274/1DP/1.2.1.1.2/09/IPIA/VIAA/003, LU reǵistrācijas Nr.ESS2009/88, 2010. [Online]. Available: http://profizgl.lu.lv/pluginfile.php/22519/mod_resource/conte nt/0/AGrinfelds AGeske/Testi izglitibaa final2.pdf [Accessed January 16, 2017]. (In Latvian)

[8] L. A. Wingate, "The Evaluation Checklist Project: The Inside Scoop on Content, Process, Policies, Impact, and Challenges," Nov 4, 2002, [Online]. Available: https://wmich.edu/sites/default/files/attachments/u350/2014/i nsidescoop.pdf. [Accessed February 6, 2017].

[9] H. M. Niegemann, S. Domagk, S. Hessel, A. Hein, M. Hupfer und A. Zobel, Kompendium multimediales Lernen. (Compendium of multimedial learning) Heidelberg: Springer, 2008, 81 p. (In German) 
[10] G. D. Rey, E-Learning: Theorien, Gestaltungsempfehlungen und Forschung. (E-learning: theories, design recommendations and research) Hogrefe AG: Bern, 2009. (In German)

[11] Swedish National Agency for Higher Education "E-learning quality. Aspects and criteria for evaluation of e-learning in higher education," Report 2008:11R, 2008.

[12] A. Usoro and G. Majewski, "Measuring Quality e-Learning in Higher Education," International Journal of Global Management Studies, vol.1, pp. 1-32, 2009.

[13] E. Bratengeyer, "Entwicklung eines Web-basierten Tools zur eLearning-Qualitätsevaluation" (Development of a webbased tool for eLearning quality evaluation) Hamburger eLearning-Magazin, no. 17, S. 28-31, Juli 2015. [Online]. Available: https://www.uni-hamburg.de/elearning/ hamburger-elearning-magazin-14.pdf. [Accessed February 6, 2017]. (In German)

[14] D. Dinevski, J. Jakončič, M. Lokar and B. Žnidaršič, A model for quality assessment of electronic learning material: Proceedings of the ITI 2010, 32nd International Conference on Information Technology Interfaces, pp. 343-348, 2010.

[15] C.-Ch. Fey, Kostenfreie Online-Lehrmittel: eine kritische Qualitätsanalyse. (Free online teaching material: a critical quality analysis) Bad Heilbrunn: Klinkhardt, 2015, 320 S. (In German)

[16] C. Pappas, "The Ultimate eLearning Course Design Checklist," April 10, 2014. [Online]. Available: http://elearningindustry.com/the-ultimate-elearning-coursedesign-checklist. [Accessed February 6, 2017].

[17] Z. Krajcso, "Classification and quality criteria for Open Educational Resources in the field of foreign language learning," Journal of Language and Cultural Education, vol. 4, Iss. 1, p. 48-59, 2016.

[18] D. Madden, "17 elements of good online courses," Aug 3, 1999. [Online]. Available: https://www.honolulu.hawaii.edu/ facdev/guidebk/online/web-elem.htm. [Accessed January 16, 2017].

[19] A. Sperl, „Bewertung der Qualität von Lehrmaterialien,“ (Assessment of the quality of e-learning materials) Dec.8, 2015. [Online]. Available: https://alexandersperl.wordpress. com/2015/12/08/bewertung-der-qualitat-von-lehrmaterialien/ [Accessed February 6, 2017]. (In German)

[20] U. Grabe, L. Ionica, K. Kunze, P. Schneider und A. Schulz, „Entwicklung eines Bewertungsverfahrens zur Vergabe des @ ward Preis für multimediales Lehren und Lernen an der Universität Halle," (Development of an evaluation procedure for awarding the @ward Prize for multimedia teaching and learning at the University of Halle) Hamburger eLearningMagazin, no.17, S. 37-39, Juli 2015. [Online]. Available: https://www.uni-hamburg.de/elearning/hamburger-elearningmagazin-14.pdf. [Accessed February 6, 2017]. (In German)

[21] C. Schoor and H. Körndle, "Checklist for a Didactically Sound Design of eLearning Content," no. 29, June 2012. [Online]. Available: https://www.scribd.com/document/ 99490612/Cornelia-Schoor-Elearning-Papers-2012-checklistfor-a-Didactically-Sound-Design-of-Elearning-Content. [Accessed February 6, 2017].

[22] R. C. Clark and C. Lyons, Graphics for Learning: Proven Guidelines for Planning, Designing, and Evaluating Visuals in Training Materials, 2nd Edition, San Francisco, CA: Pfeiffer, 2010, $420 \mathrm{p}$.

[23] Swedish Civil Contingencies Agency, "Developing Training Material Guide," 2012. [Online]. Available: https://www. msb.se/RibData/Filer/pdf/26433.pdf. [Accessed February 6, 2017].

[24] E. J. Davidson, Evaluation Methodology Basics The Nuts and Bolts of Sound Evaluation Thousand Oaks, CA: SAGE Publications, 2005, $280 \mathrm{p}$. 